\title{
Literatura białoruska w Polsce po roku 1989. O potrzebie tworzenia bazy literackiej
}

Nowe warunki polityczne, społeczne i ekonomiczne w Polsce po $1989 \mathrm{r}$. i powstanie w 1991 r. suwerennego państwa, Republiki Białoruś, stworzyły inne niż dotychczas możliwości dla promocji literatury białoruskiej i badań nad literaturą białoruską w Polsce. Obok istniejących pojawiły się kolejne uniwersyteckie katedry i zakłady oraz jednostki naukowe. Realizują one często w ujęciu interdyscyplinarnym - nowe tematy badawcze, uwzględniające literaturę białoruską w Polsce i na Białorusi. Wyniki ich prezentowane są w afiliowanych publikacjach naukowych: książkach, pracach zbiorowych, czasopismach (w tym internetowych). Powstały też - nie tylko na Białostocczyźnie, lecz także w innych miejscach kraju - liczne organizacje pozarządowe (fundacje, towarzystwa i stowarzyszenia), których celem jest w dużym stopniu promocja współczesnej literatury krajów Europy Środkowej i Wschodniej, w tym białoruskiej. Świadczą o tym liczne wydawnictwa książkowe, publikacje w czasopismach literackich i na stronach internetowych. Obejmują one głównie literaturę piękną i jej przekłady.

This is an Open Access article distributed under the terms of the Creative Commons Attribution 3.0 PL License (creativecommons.org/licenses/by/3.0/pl/), which permits redistribution, commercial and non-commercial, provided that the article is properly cited. (C) The Author(s) 2014. 
Potwierdzają to informacje zaczerpnięte głównie ze stron internetowych. Zacznijmy od ośrodków uniwersyteckich. Najstarszym ośrodkiem badającym literaturę białoruską i prowadzącym studia z jej zakresu jest Katedra Białorutenistyki na Wydziale Lingwistyki Stosowanej Uniwersytetu Warszawskiego ${ }^{1}$. Od 1998 r. wydaje ona rocznik „Acta Albaruthenica” pod redakcją Mikołaja Chaustowicza i Mikołaja Timoszuka. Na tym samym wydziale od 2001 r. istnieje Katedra Studiów Interkulturowych Europy Środkowo-Wschodniej.

„Misją Katedry jest dążenie do coraz pełniejszego i prawdziwszego rozumienia «sytuacji interkulturowej» w regionie w ujęciu historycznym i współczesnym. W tę sytuację interkulturową zostaliśmy jako Katedra «Wrzuceni» nie tylko w sensie założonego programu badawczego, lecz także - a może przede wszystkim - jako zespół ludzi o różnych zapleczach etnicznych i kulturowych, zdecydowany wspólnie penetrować [...] przestrzeń interkulturową Europy Środkowej i Wschodniej. Sytuacja interkulturowa Katedry stała się więc modelem sytuacji interkulturowej regionu" (Koźbiał, b.d.).

Jak się okazuje, w owej przestrzeni ważne miejsce zajmuje literatura białoruska. Świadczą o tym treści zamieszczone w afiliowanych przez jednostkę czasopismach. Jest to ukazujące się nieregularnie od $2002 \mathrm{r}$, pismo poświęcone badaniom przekładowym „Recepcja. Transfer. Przekład” i wychodzący od 2007 r. półrocznik o profilu kulturoznawczym „Studia Interkulturowe Europy Środkowo-Wschodniej”. Redaktorem obu czasopism jest Jan Koźbiał.

Wraz z utworzeniem w 1997 r. samodzielnego Uniwersytetu w Białymstoku Katedra Kultury Białoruskiej powstała jako jednostka na Wydziale Humanistycznym, a po zmianach organizacyjnych - na Wydziale Filologicznym. Prowadzi się tam badania o charakterze interdyscyplinarnym dotyczące Białorusi, jej historii i kultury. Na tym samym wydziale badania z zakresu literatury białoruskiej prowadzone są w powstałej w 1999 r. Katedrze Filologii Białoruskiej - jednostce funkcjonującej w strukturze Instytutu Filologii Wschodniosłowiańskiej². Od 2001 r. Instytut wydaje rocznik „Studia Wschodniosłowiańskie” - obecnie pod redakcją Leonardy Dacewicz. Jednak

${ }^{1}$ Katedra Białorutenistyki powstała jako Zakład Filologii Białoruskiej w 1956 r., a w 1977 r. została przekształcona w Katedrę Filologii Białoruskiej. Obecna nazwa jednostki funkcjonuje od 2005 r. Zob. http://www.kb.uw.edu.pl/ (Katedra Białorutenistyki UW, b.d.).

${ }^{2}$ W 1992 r. jeszcze w Filii Uniwersytetu Warszawskiego w Białymstoku powstała Pracownia Białorutenistyczna, przekształcona w 1996 r. w Zakład Filologii Białoruskiej, a od 1999 r. w Katedrę Filologii Białoruskiej. 
problematyka dotycząca literatury białoruskiej w dużym stopniu omawiana jest na łamach rocznika „Białorutenistyka Białostocka” ukazującego się od 2009 r. pod redakcją Haliny Twaranowicz.

Badania nad literaturą białoruską prowadzone są w powstałym na początku lat 90. Zakładzie Białorutenistyki Instytutu Filologii Słowiańskiej na Wydziale Humanistycznym Uniwersytetu Marii Curie-Skłodowskiej w Lublinie. Wyniki badań są umieszczane w ukazującym się od 2007 r. pod redakcją Michała Sajewicza roczniku „Studia Białorutenistyczne”. Pracownicy Zakładu są inicjatorami serii wydawniczej dotyczącej polsko-białoruskich związków literackich, kulturowych, językowych i historycznych. Ostatni tom pt. „Polsko-białoruskie związki kulturowe, literackie i językowe” ukazał w 2010 r. pod redakcją Michała Sajewicza i Siarhieja Kawalowa.

W 1995 r. na Uniwersytecie Opolskim w Instytucie Filologii Wschodniosłowiańskiej Wydziału Filologicznego powstał Zakład Białorutenistyki i Ukrainistyki. Problematyka literatury białoruskiej prezentowana jest w serii naukowej „Studia i Szkice Slawistyczne” pod redakcją Bronisława Kodzisa. Jej wydawanie poprzedziły i zainspirowały wcześniejsze prace Instytutu ${ }^{3}$. Z kolei Studia i szkice slawistyczne. Literatura - Kultura - Język z 2000 r. użyczyły tytułu i ustaliły ogólny profil serii (Instytut Filologii Wschodniosłowiańskiej, b.d.).

Badania nad literaturą białoruską znajdują się też w polu zainteresowań innych ośrodków, nieposiadających specjalistycznych jednostek naukowych. Są one realizowane w jednostkach o profilu ogólniejszym - wschodniosłowiańskim czy slawistycznym. Warto podać kilka przykładów. Na Uniwersytecie Warmińsko-Mazurskim w Olsztynie w ramach Instytutu Słowiańszczyzny Wschodniej Wydziału Humanistycznego wyniki prowadzonych badań zamieszczane są w roczniku „Acta Polono-Ruthenica” ukazującym się od 1996 r. - obecnie pod redakcją Walentego Piłata. Na Uniwersytecie Zielonogórskim badania prowadzi Zakład Literatur Wschodniosłowiańskich Instytutu Neofilologii na Wydziale Humanistycznym. Efekt organizowanych konferencji i Międzynarodowego Sympozjum Slawistycznego to książki poświęcone literaturom i językom wschodniosłowiańskim (Instytut Neofilologii Wydziału Humanistycznego, b.d.). W Instytucie Filologii Słowiańskiej na Wydziale Nauk Humanistycznym Katolickiego Uniwersytetu Lubelskiego Jana Pawła II są wydawane „Roczniki Humanistyczne”. Zeszyt siódmy tego czasopisma

3 Zob. Chlebda \& Kochman, 1996. 
poświęcono szeroko rozumianemu słowianoznawstwu. Prezentowane w nim materiały obejmują również zagadnienia dotyczące literatury białoruskiej (Roczniki Humanistyczne TN KUL, b.d.).

Jednym z kierunków badawczych istniejącego od 1954 r. Instytutu Słowianoznawstwa PAN, a od 1992 - Instytutu Slawistyki PAN, są interdyscyplinarne badania nad literaturami na obszarze Słowiańszczyzny ${ }^{4}$. O zainteresowaniu literaturą białoruską świadczą treści zamieszczone w wydawanym od 1993 r. obecnie pod redakcją Jolanty Sujeckiej - czasopiśmie poświęconym literaturom i kulturze narodów słowiańskich: „Studia Litteraria Polono-Slavica”.

Literatura białoruska stanowi jeden z problemów badawczych kwartalnika Komitetu Słowianoznawstwa PAN „Slavia Orientalis”, który po 1991 r. zmieniał nieraz miejsce wydania, wydawców i redaktorów.

Teksty z zakresu literaturoznawstwa białoruskiego i porównawczego czy ujmujące literaturę białoruską w sposób interdyscyplinarny można znaleźć $\mathrm{w}$ wielu pracach zbiorowych o charakterze jubileuszowym, tematycznym, często mających charakter cykliczny ${ }^{5}$. Tomy te ukazują się niemal we wszystkich ośrodkach naukowych w kraju, których zainteresowania badawcze obejmują literaturoznawstwo słowiańskie.

Warto też zwrócić uwagę na podejmowaną przez badaczy literatury białoruskiej problematykę. Po 1989 r. w literaturoznawstwie obecne są wciąż tematy związane z twórczością autorów skupionych wokół Białoruskiego Stowarzyszenia Literackiego „Białowieża”. Świadczą o tym tytuły prac monograficznych. O literaturze „Białowieżan” pisała Teresa Zaniewska w książkach Podróż daremna. Szkice o literaturze białoruskojęzycznej w Polsce (Zaniewska, 1992) i Strażnicy pamięci. Poezja białoruskojęzyczna w Polsce po roku 1956 (Zaniewska, 1997). Inne prace to publikacje Beaty Siwek Ojczyzna mała i duża. Poeci Białoruskiego

${ }^{4}$ http://www.ispan.waw.pl (Instytut Slawistyki Polskiej Akademii Nauk, b.d.). Zob. też 50 lat slawistyki w Polskiej Akademii Nauk (1954-2004): księga jubileuszowa Instytutu Slawistyki PAN, 2004.

${ }^{5}$ Przykład mogą stanowić publikacje cykliczne: Satyra w literaturach wschodniosłowiańskich pod red. Wandy Supy (Supa, 1993-2008), Wielkie tematy kultury w literaturach słowiańskich (zespół red.) (Wielkie tematy kultury w literaturach słowiańskich, 1997-2012), tematyczne: Ziemia w literaturach i myśli filozoficznej Słowian pod red. Wandy Laszczak i Darii Ambroziak (Laszczak \& Ambroziak, 2008), W kręgu wartości. Bóg, człowiek, świat w kulturze i literaturach wschodniosłowiańskich pod red. Anny Woźniak i Witolda Kowalczyka (Woźniak \& Kowalczyk, 2010), jubileuszowe: Na pograniczu nauk i kultur. Tom poświęcony Profesorowi Bronisławowi Kodzisowi pod red. Marii Giej i Tomasza Wielga (Giej \& Wielg, 2011). 
Stowarzyszenia Literackiego „Białowieża” wobec problematyki ojczyźnianej (Siwek, 2004) і Anny Sakowicz Беларуская літаратура ў Польшчы. Стылістычнажанравыя асаблівасиі прозы белавежан (Sakowicz, 2012).

Pojawiają się książki o nowej problematyce badawczej. Tomasz Wielg jest autorem pierwszej w Polsce monografii o Wasylu Bykowie Poetyka prozy Wasila Bykawa (Wielg, 2002), a Irena Chowańska - o Michasiu Stralcowie W poszukiwaniu siebie. Proza Michasia Stralcowa (Chowańska, 2011). Katarzyna Bortnowska w książce Białoruski postmodernizm. Liryka pokolenia Bum-Bam-Litu (Bortnowska, 2009a) jako pierwsza podjęła temat nowej poezji na Białorusi. Przedmiotem zainteresowań stały się też dramaturgia i teatr białoruski. Świadczą o tym ostatnio wydane prace Beaty Siwek Wolność ukrzyżowana. Rzecz o białoruskim dramacie i teatrze (Siwek, 2011) i Andrzeja Moskwina Teatr białoruski 1920-1930. Odrodzenie i zagłada (Moskwin, 2013). O literaturze Wielkiego Księstwa Litewskiego pisał Siarhiej Kawalou, profesor UMCS w Lublinie, w wydanych w Mińsku monografiach Героіка-эпічная паэзія Беларусі і Літвы каниа XVI cm. (Кавалёў, 1993) oraz Станаўленне польскамоўнай паэзіі у полілінгвістычнай літаратуры Беларусі эпохі Рэнесансу (Кавалёў, 2002). Nowe wyniki badań literatury białoruskiej w Polsce zostały opublikowane przez Mikołaja Chaustowicza w książce Шляхамі да беларускасиі. Нарысыь, артыкулы, эсэ (Хаўстовіч, 2010). Na uwagę zasługują też artykuły w pracach zbiorowych i czasopismach naukowych. Jeden z poruszanych tematów to analiza twórczości białoruskich klasyków: Maksima Bahdanowicza, Franciszka Bahuszewicza, Janki Łuczyny, Janki Kupały, Jakuba Kołasa i innych. Pojawiły się też nowe tematy, dotyczące chociażby współczesnej literatury białoruskiej. Artykuły o Uładzimirze Karatkiewiczu napisał Tomasz Wielg. Autorzy interesowali się literaturą łagrową związaną z nazwiskiem Franciszka Alachnowicza czy Łarysy Hienijusz (Andrzej Moskwin, Telesfor Poźniak), a także literaturą emigracyjną (Aleksander Barszczewski, Nina Barszczewska, Jerzy Traczuk). Przywoływali zapomniane nazwiska twórców białoruskich, np. Teodora Iljaszewicza, Jana Siemaszkiewicza, Kazimira Swajaka (Helena Głogowska), Józefa Reszecia (Wiesław Choruży). Trzeba zaznaczyć, że ostatnio literatura białoruska znalazła się w kręgu zainteresowań białostockiego środowiska polonistycznego. Jest ona prezentowana w „Białostockich Studiach Literaturoznawczych”, ukazujących się od 2010 r. pod redakcją Elżbiety Sidoruk i Elżbiety Konończuk. Przedmiotem badań Danuty Zawadzkiej, Elżbiety Konończuk, Katrzyny Mierzyńskiej-Sawickiej i Dariusza Kuleszy stała się głównie twórczość Sokrata Janowicza i Michała Androsiuka. 
Omówienia wymagają też organizacje pozauniwersyteckie i pozanaukowe, przedmiot ich zainteresowań stanowi bowiem sama w sobie literatura piękna. W zależności od specyfiki czytelnika jest ona prezentowana w oryginale bądź w przekładach. Do ważniejszych zadań tych organizacji zalicza się działalność wydawnicza. Czytelnik białoruskojęzyczny to przede wszystkim mniejszość białoruska w Polsce skupiona na Białostocczyźnie (Харытанюк-Міхей, 2008, ss. 12-13).

W 1956 r. jako organ Białoruskiego Towarzystwa Społeczno-Kulturalnego (BTSK) powstał w Białymstoku tygodnik „Niwa”. Po 1989 r. dokonały się w nim zmiany zarówno programowe, jak i o charakterze organizacyjnym. „Niwa” stała się tygodnikiem Białorusinów w Polsce, a jego wydawcą - Rada Programowa Tygodnika „Niwa”. W swojej koncepcji tygodnik nie stracił zainteresowania literaturą białoruską. Nadal z nieregularną częstotliwością pojawia się strona literacka, niegdyś redagowana przez członków „Białowieży”. Tygodnik organizuje Ogólnopolski Konkurs Białoruskiej Poezji i Prozy, którego pokłosiem są kolejne tomy literackie ukazujące się nakładem wydawcy „Niwy”. Ponadto Rada Programowa prowadzi szerszą działalność wydawniczą, promując literatów białoruskich z Polski i Białorusi (Ніва, b.d.). W 1998 r. wydała pierwszą antologię nowej poezji białoruskiej w przekładzie na język polski Za niebokresem Europy. Antologia nowej poezji białoruskiej 1987-1998 (Maksymiuk, 1998).

Z „Niwą” i BTSK wiąże się powstałe w 1958 r. Stowarzyszenie Literackie „Białowieża” (Лукша, 2013, s. 1). W 1990 r. „Białowieża” stała się Białoruskim Stowarzyszeniem Literackim „Białowieża”. W tym samym roku zainicjowano serię wydawniczą „Biblioteka Białoruskiego Stowarzyszenia Literackiego «Białowieża»" pod redakcją jej przewodniczącego Jana Czykwina. Od 1998 r. pod jego redakcją Stowarzyszenie wydaje czasopismo „Тэрмапілы” („Termopile”). To rocznik literacko-artystyczny i białorutenistyczny, który zamieszcza teksty głównie w języku białoruskim (Kamunikat, b.d.).

Powstałe w 1956 r. BTSK wydaje zapoczątkowane w 1959 r. „Kalendarze Białoruskie", w których publikowane są utwory literackie białoruskich poetów i prozaików. Wraz z Katedrą Filologii Białoruskiej Uniwersytetu w Białymstoku i Grodzieńskim Uniwersytetem Państwowym im. Janki Kupały współorganizuje też cykliczne konferencje „Droga ku wzajemności”, na których podejmowana jest tematyka dotycząca literatury białoruskiej.

Literatura białoruska znajduje się w polu zainteresowań Związku Białoruskiego w Rzeczypospolitej Polskiej pod przewodnictwem Eugeniusza Wappy. Z jego inicjatywy organizowane są od 1996 r. spotkania literackie 
z cyklu „Бязьмежжа”, które zrodziły się pod wpływem poezji Alesia Razanawa (Ваўранюк, 2000, ss. 4-9). Ich cel stanowi dyskusja i promocja głównie nowej literatury białoruskiej. Związek Białoruski w RP prowadzi też działalność wydawniczą. Pod wpływem „Бязьмежжа” ukazały się w latach 2000 i 2002 dwa podwójne numery białoruskiego pisma literacko-artystycznego „Правінцыя” („Prowincja”) pod redakcją Aleksandra Maksymiuka. Związek wydał też przekłady nieznanej dotąd literatury białoruskiej na język polski. W powstałej serii „Бязьмежжа” świat ujrzała książka Uładzimira Arłowa Requiem dla piły motorowej w przekładzie Olega Łatyszonka, Mirosławy Łukszy, Haliny Maksymiuk, Jana Maksymiuka, Czesława Seniucha, Aleksandra Wierzbickiego (Arłou, 2000). Celem powstałej w 2009 r. serii Radia Racja „Transgraniczne ścieżki” jest prezentowanie literatury białostocko-grodzieńskiej.

W 2009 r. w Krynkach, na bazie istniejącego od 2002 r. Stowarzyszenia Villa Sokrates, powstała Fundacja Villa Sokrates. Najważniejsze przedsięwzięcie głównego inicjatora i pomysłodawcy Fundacji Sokrata Janowicza to impreza kulturalna pod nazwą „Trialog”. Odbywające się od 1999 r. spotkania ludzi różnych środowisk twórczych i nauki koncentrują się wokół idei „Literatura - Obraz - Teatr”. Pokłosiem jest wielojęzyczny rocznik „Annus Albaruthenicus" wydawany od 2000 do 2012 r. pod redakcją Sokrata Janowicza. Owa wielojęzyczność ma na celu pokazanie literatury i kultury białoruskiej Europie i światu. Po śmierci Sokrata Janowicza - jednej z najbardziej znaczących postaci literatury białoruskiej w Polsce - zapoczątkowane przez niego działania są kontynuowane. Cel Fundacji to bowiem - jak czytamy na stronie internetowej - „pielęgnowanie i propagowanie myśli oraz idei płynących z twórczości Sokrata JANOWICZA, budowaniu nowej jakości na gruncie etosu pogranicza polsko-białoruskiego. Celem statutowym Fundacji jest budowanie mostów pomiędzy przedstawicielami różnych narodów, kultur i religii, prowadzenie działalności wydawniczej oraz działalność kulturotwórcza na polu sztuki współczesnej" (Fundacja Villa Sokrates, b.d.).

Oprócz tygodnika „Niwa” literatura białoruska w ujęciu podmiotowym i przedmiotowym pojawiała się na stronach innych gazet i czasopism wydawanych w Białymstoku. Przykładem może być powstały w 1985 r. „Tygodnik Podlaski”, od 1991 r. jako „Prawosławie”, a od 1992 r. - wychodzący po dziś „Przegląd Prawosławny”. Nie bez znaczenia jest tu publikowanie od $1990 \mathrm{r}$. dwujęzycznego polsko-białoruskiego miesięcznika „Czasopis” (Czasopis, b.d.). To białoruskie pismo społeczno-kulturalne, wychodzące obecnie pod redakcją Jerzego Chmielewskiego, zamieszcza nieregularnie rubrykę „Літаратурная 
паласа” („Rubryka literacka”), która publikuje utwory białoruskich autorów zarówno w oryginale, jak i w przekładach.

Dla odbiorcy polskojęzycznego literatura białoruska dostępna jest nade wszystko w przekładach. W formie tej periodycznie pojawia się na stronach polskich czasopism, wydawanych przez stowarzyszenia i fundacje w całej Polsce. Repertuar proponowany polskiemu czytelnikowi zależy od wielu czynników. O tym, co decyduje o wyborze przekładów szczególnie młodej literatury białoruskiej w Polsce, pisała Katarzyna Bortnowska (Bortnowska, 2009b, ss. 16-26).

Ważne miejsce w promocji literatury białoruskiej odegrały białostockie „Kartki”, wydawane przez Stowarzyszenie Literackie „Kartki”. Powstały one w 1992 r. jako pismo literackie młodych, a od 1997 r. wydawane są jako pismo literacko-artystyczne. Ukazywały się do 2005 r. pod redakcją Bogdana Dudko. Prezentowały przekłady nowej literatury białoruskiej na język polski. Pismo będące kontynuacją "Kartek” ukazało się w 2011 r. w jednym numerze pt. „Nowe Kartki”. W ramach serii „Biblioteka Kartek” ukazały się w przekładzie: sztuka Michała Aniempadystawa i Lawona Wolskiego Narodny Albom (Aniempadystau \& Wolski, 2000) i tomik poezji Alesia Razanawa Zdobywcy (Razanau, 1997) (Sawicka-Mierzyńska, 2012, ss. 296-321).

W 1990 r. powstała Fundacja Pogranicze w Sejnach, której „działalność programowa $\mathrm{w}$ całości poświęcona jest propagowaniu etosu pogranicza i budowaniu mostów pomiędzy ludźmi różnych religii, narodowości i kultur" (Ośrodek „Pogranicze - sztuk, kultur, narodów” w Sejnach, b.d.). Od 1993 r. Fundacja wydaje pod redakcją Krzysztofa Czyżewskiego magazyn środkowoeuropejski „Krasnogruda”. Na stronie internetowej czytamy: „To pismo łączące wielość tradycji i gatunków literackich. W Krasnogrudzie prezentujemy regiony i miasta Europy Środkowo-Wschodniej, gdzie wielokulturowość jest ciągle wartością żywą, gdzie tradycja jest codzienną praktyką, a także te, gdzie na styku różnych systemów (religijnych, narodowych) pojawiają się napięcia. [...] Większość numerów ma charakter monograficzny, poświęcona jest jednemu wybranemu regionowi Europy Środkowowschodniej (Bośnia, Bukowina) lub miastu (Praga)” (Ośrodek „Pogranicze - sztuk, kultur, narodów” w Sejnach, b.d.). Tak więc w 2000 r. ukazał się numer niemal w całości poświęcony literaturze i kulturze białoruskiej.

Podobne założenia towarzyszą Stowarzyszeniu Wspólnota Kulturowa „Borussia”, które powstało w 1990 r. w Olsztynie, a od 2006 r. jest kontynuowane i wspierane przez Fundację „Borussia”. Działa ona bowiem „na rzecz 
budowania i pogłębiania kultury dialogu i tolerancji między ludźmi różnych narodowości, wyznań, tradycji oraz współtworzenia społeczeństwa obywatelskiego" (Fundacja Borussia Olsztyn, b.d.). Od 1991 r. wydaje pod redakcją Roberta Traby czasopismo dotyczące kultury, literatury, historii „Borussia”, które od 1995 r. zamieszcza przekłady literatury białoruskiej na język polski. W wydawnictwie Wspólnoty Kulturowej „Borussia” ukazała się też książka Sokrata Janowicza Ojczystość: białoruskie ślady i znaki, zawierająca przekłady jego utworów literackich, esejów i wypowiedzi (Janowicz, 2001), a także przekład współczesnych opowiadań białoruskich Białoruś. Kraina otoczona wysokimi górami (Białoruś: kraina otoczona wysokimi górami, 2004).

Ważna dla literatury białoruskiej jest działalność wydawnicza Kolegium Europy Wschodniej im. Jana Nowaka-Jeziorańskiego z siedzibą we Wrocławiu. Powołana w 2001 r. jako fundacja „działa na rzecz współpracy pomiędzy narodami Europy Środkowej i Wschodniej. Swoje cele statutowe realizuje poprzez działalność edukacyjną, kulturalną, wydawniczą, programy rozwojowe wspierające transformację w krajach Europy Wschodniej, organizację spotkań, wykładów i konferencji” (Kolegium Europy Wschodniej, b.d.). Wydawnictwo Kolegium zainicjowało w ramach białoruskiego programu wydawniczego zamkniętą już serię „Biblioteka Białoruska”. Jej cel stanowiła promocja literatury białoruskiej w Polsce. W serii tej, powstałej w 2006 r., ukazały się antologie poezji białoruskiej w przekładzie na języka polski Pępek nieba. Antologia młodej poezji białoruskiej (red. Andrej Chadanowicz, Adam Pomorski) (Chadanowicz \& Pomorski, 2006), a także Nie chyliłem czoła przed moca. Antologia poezji białoruskiej od XV do XX wieku (red. Lawon Barszczewski i Adam Pomorski) (Barszczewski \& Pomorski, 2008). Ukazały się tłumaczenia poszczególnych autorów, jak Andreja Chadanowicza, Uładzimira Arłowa, Ryhora Baradulina, Wasila Bykawa, Alesia Razanawa, Swiatłany Aleksijewicz, Alhierda Bacharewicza, Ihara Babkowa, Walancina Akudowicza, Uładzimira Niaklajewa. Obecnie Kolegium jest współwydawcą serii „Biblioteka Grodzieńska”.

Krajeńskie Stowarzyszenie Kulturalne z siedzibą w Więcborku wydaje kwartalnik literacko-artystyczny „Pobocza” poświęcony kulturze Europy Środkowej i Wschodniej. Redagowane przez Pawła Szydeła pismo w latach 2004-2008 publikowało literaturę białoruską w przekładach na język polski (Kwartalnik Literacko-Artystyczny Pobocza, b.d.).

Warto zwrócić uwagę i na wydawnictwa, w których ukazały się książki autorów białoruskich w przekładzie na język polski. Oto niektóre przykłady. W wydawnictwie „Czarne” z siedzibą w Wołowcu ukazała się książka Mińsk. 
Przewodnik po Mieście Słońca (2008) w tłumaczeniu Małgorzaty Buchalik (Klinau, 2008), a także reportaże Swietłany Aleksijewicz Wojna nie ma w sobie nic $z$ kobiety (Aleksijewicz, 2010), Czarnobylska modlitwa. Kronika przyszłości (Aleksijewicz, 2012) i Ostatni świadkowie. Utwory solowe na głos dziecięcy (Aleksijewicz, 2013) - wszystkie w przekładzie z języka rosyjskiego Jerzego Czecha. Gdańskie wydawnictwo „Słowo/Obraz Terytoria” w 2009 r. wydało tom Europejskiego Poety Wolności Uładzimira Arłowa Prom przez kanał La Manche w tłumaczeniu Adama Pomorskiego (Arłou, 2009). W 2011 r. w warszawskim Wydawnictwie Literatów i Dziennikarzy POD WIATR ukazały się wiersze i poematy Uładzimira Niaklajewa Pożegnalny gest Zygmunta w przekładzie Czesława Seniucha (Niaklajeu, 2011). W 2013 r. w wydawnictwie "Zeszyty Poetyckie” ukazał się tom poezji Wielkie Księstwo Białoruś Witala Woranawa w przekładzie Moniki Uranek (Voranau, 2013). Największy rozgłos zrobiła książka Natalki Babiny Miasto ryb w przekładzie Małgorzaty Buchalik (Babina, 2010). Ukazała się ona nakładem poznańskiego wydawnictwa „Rebis”. W 2012 r. po raz pierwszy w Polsce ukazała się książka klasyka białoruskiej powieści historycznej Uładzimira Karatkiewicza pod tytułem Chrystus wyladował w Grodnie w warszawskiej Oficynie 21 w przekładzie Małgorzaty Buchalik (Karatkiewicz, 2012). W 2004 r. w Wydawnictwie Uniwersytetu Marii Curie-Skłodowskiej w Lublinie ukazał się zbiór dramatów Siarhieja Kawalowa Zmęczony diabeł. Dramaty w przekładzie Teresy Giedz, Beaty Siwek i Michała Sajewicza (Kawalou, 2004), a w 2013 r. Radzyńskie Stowarzyszenie Inicjatyw Lokalnych w Radzyniu Podlaskim wydało zbiór przekładów Labirynt. Antologia wspótczesnego dramatu białoruskiego pod redakcją Beaty Siwek (Siwek, 2013).

Poszczególne wydawnictwa białostockie drukowały również przekłady literatury białoruskiej. I tak w 1999 roku ukazał się przekład opowiadań Wasila Bykawa Ściana (Bykau, 1999). Białoruskie Towarzystwo Historyczne wydało wspomnienia syberyjskie Anieli Kotkowicz i Weroniki Kotkowicz-Klentak w przekładzie Anny Sobeckiej (Katkovich \& Katkovich-Klentak, 2003). W wydawnictwie „Orthdruk” ukazały się książki „Białowieżan”: w 1999 r. w przekładzie Czesława Seniucha Nostalgie Alesia Barskiego (Barski, 1999), a w 2000 r. Wiktora Szweda Śmiech nie grzech (Szwed, 2000b) i Lata wiatr skrzydlaty (Szwed, 2000a) w przekładzie autorskim.

Przekłady literatury białoruskiej w Polsce rozproszone są w wielu czasopismach i gazetach. Publikowano w nich utwory twórców białoruskich różnych pokoleń. Przykładem niech będą wybrane tytuły: „Przegląd Tygodniowy”, „Słowo”, „Literatura na Świecie”, „Akcent”, „Kresy”, „Integracje”, „Agricola”, 
„Dyskusja”, „Kresy Literackie”, „Białostocki Przegląd Kresowy”, „Czas Kultury”, ostatnio „Ha! Art” i „Bliza”. Mają niewielki nakład i często zasięg lokalny.

$\mathrm{Z}$ dokonanego przeglądu wynika, że po 1989 r. przedmiotem zainteresowania wydawców jest głównie młoda, dotąd nieznana w Polsce, literatura białoruska. Pojawiło się nowe pokolenie tłumaczy, związane nie tylko z etniczną Białorusią (Тычка, 2000, ss. 159-166). Oprócz Czesława Seniucha, Adama Pomorskiego i Anny Sobeckiej literaturę białoruską tłumaczą Katarzyna Kotyńska, Małgorzata Buchalik, Katarzyna Bortnowska, Beata Siwek i inni.

Przedstawiony materiał to wynik wieloletnich poszukiwań. Jest on zebrany w postaci bibliografii w pliku wersji Word. Największy problem stanowiło dotarcie do dokumentów. Pomogło w tym doświadczenie zdobyte podczas tworzenia bibliografii tradycyjnych dotyczących literatury białoruskiej. Praca ta jest bowiem kontynuacją opracowanych przeze mnie bibliografii literackich: Literatura białoruska $w$ Polsce. Bibliografia przekładów za lata 1945-1994 (Charytoniuk, 1996) i Polskie białorutenika literackie. Bibliografia przedmiotowa 1945-1998 (Charytoniuk, 1998). Są one jednym ze źródeł bibliograficznych dla badaczy i zainteresowanych literaturą białoruską w Polsce powojennej. Bibliografie te mają charakter retrospektywny. Rejestrują dokumenty, które ukazały się w Polsce do połowy lat dziewięćdziesiątych. Głównym źródłem poszukiwań dokumentów były bibliografie tradycyjne: ogólne, jak Przewodnik Bibliograficzny (do 1998 roku), Bibliografia Zawartości Czasopism (do 1998 r.); dziedzinowe: Polska Bibliografia Literacka (do 1986 r.), Bibliografia prac z zakresu slawistyki. Literaturoznawstwo (t. 2, 1968-1981), Bibliografia literatury ttumaczonej na język polski wydanej w latach 1945-1977 (t. 2), Literatura piękna. Adnotowany rocznik bibliograficzny (1954-1984); regionalne: Bibliografia regionu białostockiego (t. 1-4, 1944-1980), Bibliografia województw: białostockiego, łomżyńskiego, suwalskiego (t. 5, 1981-1985) (Bibliografia Województw: Białostockiego, Łomżyńskiego i Suwalskiego, 1995). Wykorzystane zostały także wcześniejsze bibliografie dotyczące tego zagadnienia, jak Bibliografia przekładów z literatury białoruskiej na język polski za okres 1971-1982 (Bibliografia przekładów z literatury białoruskiej, 1982, ss. 5-7) i Przekłady Kazimierza Andrzeja Jaworskiego z poezji białoruskiej (opis bibliograficzny za lata 1935-1973) (Szerszunowicz, 1985, ss. 124-130).

Bibliografia przedmiotowa rejestruje wydawnictwa zwarte, artykuły w wydawnictwach naukowych i popularnych oraz czasopismach ukazujących się z różną częstotliwością. Uwzględnia dokumenty z pogranicza literatury, w tym dotyczące literatury ludowej, dziecięcej, a także $\mathrm{z}$ dziedziny folkloru, 
drukarstwa i czasopiśmiennictwa. Rejestruje recenzje książek białoruskiej literatury pięknej, sztuk teatralnych, literaturoznawczych prac naukowych, wydanych w Polsce bądź poza jej granicami. Nie zostały w niej ujęte materiały publicystyczno-informacyjne, np. dotyczące spotkań, wieczorów autorskich, wizyt pisarzy i inne informacje ulotne. Bibliografia porządkuje materiał w układzie chronologicznym; w obrębie roku stosuje układ alfabetyczny nazwisk, a w wypadku ich braku - tytułów. Poszukiwanie ułatwia skorowidz nazwisk (Charytoniuk, 1998, s. 5).

Z kolei bibliografia podmiotowa rejestruje przekłady dzieł autorów białoruskich i utworów anonimowych ukazujące się w formie wydawnictw zwartych lub fragmentów w wydawnictwach zwartych i ciągłych. Opis bibliograficzny wzbogacony jest o adnotacje: antologie zawierają nazwiska autorów i tłumaczy, a w przypadku książki jednego autora - tłumaczy. Bibliografia zawiera indeks autorów i indeks nazwisk (tłumacze, autorzy wstępów, ilustratorzy, autorzy antologii), a także wykaz wydawnictw ciągłych, w których zamieszczone były przekłady literatury białoruskiej (Charytoniuk, 1996, ss. 5-6).

Uzupełnienie może stanowić też praca Jana Czykwina Беларуская літаратура Польшчы. Бібляграбічны даведнік 1957-1998, rejestrująca białoruską literaturę piękną, która ukazała się w „Niwie”, „Czasopisie” i „Białoruskich Kalendarzach", a także książki autorów związanych ze stowarzyszeniem „Białowieża”. Bibliografię uzupełnia indeks nazwisk (Чыквін, 1998, ss. 5-6). Kontynuacją pracy jest spis literatury wydanej w latach 1958-2003 przez „Białowieżan” (Чыквін, 2003, ss. 5-6).

Spośród tradycyjnych bibliografii trzeba zwrócić uwagę na istniejące prace magisterskie o charakterze bibliograficznym. Przykładem może być praca Jolanty Falkowskiej Sokrat Janowicz (Sakrat Ânovič). Materiały do bibliografii podmiotowo-przedmiotowej za lata 1956-2003, obroniona pod kierunkiem prof. dr hab. Pauliny Buchwald-Pelc na Wydziale Historycznym UW w 2005 r. (Falkowska, 2005), i Emilii Kojtych Wiktor Szwed - biobibliografia, napisana pod kierunkiem prof. Zoi Jaroszewicz-Pieresławcew i obroniona w 2010 r. na Wydziale Humanistycznym UWM w Olsztynie (Kojtych, 2010).

Oprócz przedstawionych bibliografii tradycyjnych ważnym źródłem okazały się zasoby Internetu. Istotne informacje zostały zaczerpnięte $\mathrm{z}$ katalogów online bibliotek naukowych i publicznych. Niezbędnych danych na temat gromadzonych dokumentów dostarczyły bibliografie dostępne $\mathrm{w}$ formie cyfrowej. To przede wszystkim Polska Bibliografia Literacka (za lata 1988-2000) (Polska Bibliografia Literacka: za lata 1988-2000, b.d.) tworzona przez Instytut 
Badań Literackich PAN i Bibliografia województwa podlaskiego (za lata 1986-2011) Książnicy Podlaskiej w Białymstoku (Bibliografia województwa podlaskiego: za lata 1986-2011, 2013, b.d.), a w stopniu mniejszym - bazy danych Biblioteki Narodowej, jak Przewodnik Bibliograficzny (Przewodnik Bibliograficzny, 2013) i Bibliografia Zawartości Czasopism (Bibliografia Zawartości Czasopism, 2013). Jak się okazało, znacznie mniej dokumentów na temat literatury białoruskiej gromadzą repozytoria naukowe, ze względu na ich zbyt ogólny profil i kryterium selekcyjności. Cennych informacji dostarczyły strony internetowe poszczególnych jednostek naukowych, wydawnictw (nie tylko naukowych) i czasopism (w tym literackich, tygodników i gazet). Poza tym ważnym źródłem danych jest białoruska biblioteka internetowa Kamunikat (Kamunikat, b.d.).

Dokumenty były także wynikiem bezpośrednich poszukiwań. Zdarzało się, że nierejestrowane w bazach danych czy katalogach bibliotecznych pozycje bibliograficzne przypadkiem trafiały z półek księgarskich albo były rekomendowane przez użytkowników.

Z poszukiwań bibliograficznych wynika, że literatura białoruska rozpatrywana $\mathrm{z}$ punktu widzenia podmiotu i przedmiotu jest w znacznym stopniu rozproszona. Dopiero kompilacja materiału ze wszystkich podanych źródeł daje możliwość spojrzenia na stan literaturoznawstwa i literatury białoruskiej w Polsce. Jest więc ogromny sens w kontynuowaniu prac bibliograficznych. Wydaje się to dzisiaj niezwykle ważne, gdyż - jak zauważają inni badacze - „mimo istnienia Internetu, odczuwa się powszechnie dotkliwy brak informacji o nowszych publikacjach, o planach badawczych i działalności ośrodków slawistycznych w kraju i za granicą" (Instytut Filologii Wschodniosłowiańskiej, b.d.). Powinna to jednak być już nie tradycyjna bibliografia, lecz jej wersja zmodernizowana - baza bibliograficzna. Nie ulega wątpliwości, że forma tradycyjna jest już dziś mniej popularna i mniej dostępna ze względu na ogólne tendencje: większość użytkowników korzysta z zasobów Internetu, zmniejszył się nakład książek naukowych, nie zawsze trafiają jako egzemplarz obowiązkowy do bibliotek. Warto dodać, że w Polsce, oprócz wspomnianej Polskiej Bibliografii Literackiej, nie ma bazy, która rejestrowałaby dokumenty o literaturze białoruskiej i innych literaturach słowiańskich.

Istnienie takiej bazy mogłoby choć w części zaspokoić potrzeby zarówno badaczy, jak i czytelników zainteresowanych literaturą białoruskojęzyczną i białoruską w Polsce. Dopiero uporządkowanie dokumentów i stworzenie właściwego systemu poszukiwań pozwolą na dokonanie analizy stanu badań zarówno nad 
literaturoznawstwem białoruskim, jak i nad oceną obecności i zainteresowania literaturą mniejszości białoruskiej i wschodnich sąsiadów Polski.

Baza powinna mieć charakter podmiotowo-przedmiotowy. O kryterium doboru zadecyduje miejsce publikacji dokumentu - w Polsce od 1989 r., bez względu na język publikacji. Zapis powinien zachować język oryginału. Z czasem mógłby zasięgiem obejmować inne literatury słowiańskie w Polsce. Zamierzenia te potrzebują opracowania merytorycznego projektu, który uwzględniałby potrzeby opracowania technicznego. Niewątpliwie, przykład mogłaby stanowić istniejąca baza językoznawstwa slawistycznego iSybislaw.

\section{Bibliografia}

50 lat slawistyki w Polskiej Akademii Nauk (1954-2004): ksiega jubileuszowa Instytutu Slawistyki PAN. (2004). Warszawa: Slawistyczny Ośrodek Wydawniczy.

Aleksijewicz, S. A. (2010). Wojna nie ma $w$ sobie nic $z$ kobiety. (J. Czech, Tłum.). Wołowiec: Wydawnictwo Czarne.

Aleksijewicz, S. A. (2012). Czarnobylska modlitwa: kronika przyszłości. (J. Czech, Tłum.). Wołowiec: Wydawnictwo Czarne.

Aleksijewicz, S. A. (2013). Ostatni świadkowie: utwory solowe na głos dziecięcy. (J. Czech, Tłum.). Wołowiec: Wydawnictwo Czarne.

Aniempadystau, M., \& Wolski, L. (2000). Narodny albom: p'esa - scenariusz. (A. Wawrzeniuk, $\&$ M. Wawrzeniuk, Tłum.). Białystok: Biblioteka Kartek.

Arłou, U. (2000). Requiem dla pity motorowej. (O. Łatyszonek, M. Łuksza, H. Maksymiuk, J. Maksymiuk, C. Seniuch, \& A. Wierzbicki, Tłum., J. Maksymiuk, Red.). Białystok: Związek Białoruski w RP.

Arłou, U. A. (2009). Prom przez kanał La Manche: wiersze. (A. Pomorski, Tłum.). Gdańsk: Wydawnictwo Słowo/Obraz Terytoria.

Babina, N. (2010). Miasto ryb. (M. Buchalik, Tłum.). Poznań: Dom Wydawniczy Rebis.

Barski, A. (1999). Nostalgie. (C. Seniuch, Tłum.). Białystok: Orthdruk.

Barszczewski, L., \& Pomorski, A. (Red.). (2008). Nie chyliłem czoła przed moca: antologia poezji białoruskiej od XV do XX wieku. Wrocław: Kolegium Europy Wschodniej im. Jana Nowaka-Jeziorańskiego.

Białoruś: kraina otoczona wysokimi górami. (2004). Olsztyn: Wspólnota Kulturowa „Borussia”. Bibliografia przekładów z literatury białoruskiej na język polski za okres 1971-1982. (1982).

Bibliografia Województw: Białostockiego, Łomżyńskiego i Suwalskiego. (1995) (T. 5: 1981-1985). Białystok: Wojewódzka Biblioteka Publiczna im. Łukasza Górnickiego w Białymstoku.

Bibliografia województwa podlaskiego: za lata 1986-2011. (b.d.). Pobrano 20 września 2013, $\mathrm{z}$ http://katalog.ksiaznicapodlaska.pl 
Bibliografia Zawartości Czasopism. (b.d.). Pobrano 20 września 2013, z http://www.bn.org.pl Bortnowska, K. (2009a). Białoruski postmodernizm: liryka pokolenia Bum-Bam-Litu. Warszawa: Wydawnictwa Uniwersytetu Warszawskiego.

Bortnowska, K. (2009b). Młoda literatura białoruska a polski rynek wydawniczy. Acta Albaruthenica, 9, 16-26.

Bykau, W. (1999). Ściana. (C. Seniuch, Tłum.). Białystok: SETPro.

Chadanowicz, A., \& Pomorski, A. (Red.). (2006). Pępek nieba: antologia młodej poezji białoruskiej. Wrocław: Kolegium Europy Wschodniej im. Jana Nowaka-Jeziorańskiego.

Charytoniuk, G. (1996). Literatura białoruska w Polsce. Bibliografia przekładów za lata 1945-1994. Białystok: Białoruskie Stowarzyszenie Literackie „Białowieża”.

Charytoniuk, G. (1998). Polskie białorutenika literackie. Bibliografia przedmiotowa 1945-1998. Białystok: Białoruskie Stowarzyszenie Literackie „Białowieża”.

Chlebda, W., \& Kochman, S. (Red.). (1996). Frazeologia i religia. Opole: Uniwersytet Opolski. Instytut Filologii Polskiej.

Chowańska, I. (2011). W poszukiwaniu siebie: proza Michasia Stralcowa. Olsztyn: Centrum Badań Europy Wschodniej Uniwersytetu Warmińsko-Mazurskiego.

Czasopis. (b.d.). Pobrano 20 września 2013, z http://czasopis.pl

Falkowska, J. (2005). Sokrat Janowicz (Sakrat Ânovič): materiały do bibliografii podmiotowo-przedmiotowej za lata 1956-2003 (Nieopublikowana praca magisterska). Wydział Historyczny Uniwersytetu Warszawskiego. Warszawa.

Fundacja Borussia Olsztyn. (b.d.). Pobrano 20 września 2013, z http://www.borussia.pl

Fundacja Villa Sokrates. (b.d.). Pobrano 20 września 2013, z http://vimeo.com/user20847765

Giej, M., \& Wielg, T. (Red.). (2011). Na pograniczu nauk i kultur: tom poświęcony Profesorowi Bronisławowi Kodzisowi. Opole: Uniwersytet Opolski.

Instytut Filologii Wschodniosłowiańskiej. (b.d.). Pobrano 20 września 2013, z http://ifw.uni. opole.pl

Instytut Neofilologii Wydziału Humanistycznego. (b.d.). Pobrano 20 września 2013, z http://www. in.uz.zgora.pl/index.php/badania-naukowe/nasze-ksiazki

Instytut Slawistyki Polskiej Akademii Nauk. (b.d.). Pobrano 20 września 2013, z http://ispan.waw.pl Janowicz, S. (2001). Ojczystość: białoruskie ślady i znaki. (R. Traba, Red.). Olsztyn: Wspólnota Kulturowa „Borussia”.

Kamunikat. (b.d.). Pobrano 20 września 2013, z http://kamunikat.org

Karatkiewicz, U. S. (2012). Chrystus wylądowat w Grodnie: (ewangelia Judasza). (M. Buchalik, Tłum.). Warszawa: Oficyna 21.

Katedra Białorutenistyki Uniwersytetu Warszawskiego. (b.d.). Pobrano 20 września 2013, z http://www.kb.uw.edu.pl

Kawalou, S. (2004). Zmęczony diabet: dramaty. (Giedz, M. Sajewicz, \& B. Siwek, Tłum.). Lublin: Wydawnictwo Uniwersytetu Marii Curie-Skłodowskiej.

Klinau, A. (2008). Mińsk: przewodnik po Mieście Słońca. (M. Buchalik, Tłum.). Wołowiec: Wydawnictwo Czarne. 
Kodzis, B., Kochman, S., \& Danecka, I. (Red.). (1997). Literatury i języki Słowian Wschodnich: stan obecny i tendencje rozwojowe (T. 1-2). Opole: Uniwersytet Opolski.

Kojtych, E. (2010). Wiktor Szwed - biobibliografia (Nieopublikowana praca magisterska). Wydział Humanistyczny Uniwersytetu Warmińsko-Mazurskiego. Olsztyn.

Kolegium Europy Wschodniej. (b.d.). Pobrano 20 września 2013, z http://www.kew.org.pl

Kotkowicz, A., \& Kotkowicz-Klentak, V. (2003). Od Budsławia do GUŁagu. (A. Sobecka, Tłum.). Białystok: Białoruskie Towarzystwo Historyczne.

Koźbiał, J. (b.d.). O Katedrze. Pobrano 20 września 2013, z http://www.ksi.uw.edu.pl

Kwartalnik Literacko-Artystyczny Pobocza. (b.d.). Pobrano 20 września 2013, z http://kwartalnik-pobocza.pl

Laszczak, W., \& Ambroziak, D. (Red.). (2008). Ziemia w literaturach i myśli filozoficznej Słowian. Opole: Wydawnictwo Uniwersytetu Opolskiego.

Maksymiuk, J. (Red.). (1998). Za niebokresem Europy: antologia nowej poezji białoruskiej 1987-1998. Białystok: Rada Programowa Tygodnika „Niwa”.

Moskwin, A. (2013). Teatr białoruski 1920-1930: odrodzenie i zagłada. Toruń: Oficyna Wydawnicza Kucharski.

Niaklajeu, U. (2011). Pożegnalny gest Zygmunta: wiersze i poematy. (C. Seniuch, Tłum.). Warszawa: Oficyna Literatów i Dziennikarzy POD WIATR.

Niva. (b.d.). Pobrano 20 wrzesień 2013, z http://niva.bialystok.pl Ośrodek „Pogranicze - sztuk, kultur, narodów” w Sejnach. (b.d.). Pobrano 20 września 2013, z http://pogranicze.sejny.pl

Polska Bibliografia Literacka: za lata 1988-2000. (b.d.). Pobrano 20 września 2013, z http:// pbl.ibl.poznan.pl/dostep

Polsko-białoruskie związki literackie i kulturalne: setna rocznica urodzin Janki Kupały i Jakuba Kołasa. (1982). Warszawa: Towarzystwo Przyjaźni Polsko-Radzieckiej.

Przewodnik Bibliograficzny. (b.d.). Pobrano 20 września 2013, z http://www.bn.org.pl

Razanau, A. (1997). Zdobywcy. (O. Łatyszonek, Tłum.). Białystok: Kartki.

Roczniki Humanistyczne TN KUL. (b.d.). Pobrano 20 września 2013, z http://www.kul.pl/ roczniki-humanistyczne-tn-kul-seria-slowianoznawstwo,art_4304.html

Sakowicz, А. (2012). Беларуская літаратура ў Польшчы: стылістычна-жанравыя асаблівасиі прозы белавежан. Białystok.

Sawicka-Mierzyńska, K. (2012). Prowincja jako pole aktywności Stowarzyszenia Artystycznego „Kartki” W K. Kościewicz \& M. Kochanowski (Red.), Podlasie w literaturze - literatura Podlasia (po 1989 roku): nowoczesność-regionalizm-uniwersalizm (ss. 296-321). Białystok: Trans Humana Wydawnictwo Uniwersyteckie.

Siwek, B. (2004). Ojczyzna duża i mała: poeci Białoruskiego Stowarzyszenia Literackiego „Białowieża" wobec problematyki ojczyźnianej. Lublin: Wydawnictwo KUL.

Siwek, B. (2011). Wolność ukrzyżowana: rzecz o białoruskim dramacie i teatrze. Lublin: Wydawnictwo KUL.

Siwek, B. (Red.). (2013). Labirynt: antologia współczesnego dramatu białoruskiego. Radzyń Podlaski: Radzyńskie Stowarzyszenie Inicjatyw Lokalnych. 
Supa, W. (Red.). (1993-2008). Satyra w literaturach wschodniosłowiańskich (T. 1-7). Białystok: Wydawnictwo Uniwersytetu w Białymstoku.

Szerszunowicz, W. (1985). Kazimierz Andrzej Jaworski jako tłumacz i popularyzator poezji białoruskiej. Studia Polono-Slavica-Orientalia. Acta Litteraria, 9, 124-130.

Szwed, W. (2000a). Lata wiatr skrzydlaty. (W. Szwed, Tłum.). Białystok: Orthdruk.

Szwed, W. (2000b). Smiech nie grzech. Białystok: Orthdruk.

Voranau, V. (2013). Wielkie Księstwo Białoruś. (M. Uranek, Tłum.). Gniezno: Zeszyty Poetyckie.

Wielg, T. (2002). Poetyka prozy Wasila Bykawa. Opole: Wydawnictwo Uniwersytetu Opolskiego.

Wielkie tematy kultury w literaturach słowiańskich. (1997-2012) (T. 1-10). Wrocław: Wydawnictwo Uniwersytetu Wrocławskiego.

Woźniak, A., \& Kowalczyk, W. (Red.). (2010). W kręgu wartości: Bóg, człowiek, świat w kulturze i literaturach wschodniosłowiańskich. Lublin: Wydawnictwo Uniwersytetu Marii Curie-Skłodowskiej.

Zaniewska, T. (1992). Podróż daremna: szkice o literaturze białoruskojęzycznej w Polsce. Białystok: Biblioteczka Białoruskiego Stowarzyszenia Literackiego „Białowieża”.

Zaniewska, T. (1997). Strażnicy pamięci: poezja białoruskojęzyczna w Polsce po roku 1956. Białystok: Trans Humana.

Ваўранюк, М. (2000). Чартапалох на мяжы. Правінцыљя, 1-2, 4-9.

Кавалёу, С. В. (1993). Героіка-эпічная паэзія Беларусі і Літвы канца XVI cm. Мінск: Унівэрсытэцкае.

Кавалёў, С. В. (2002). Станаўленне польскамоўнай паэзіі ў полілінгвістычнай літаратуры Беларусі эпохі Рэнесансу. Мінск: БДУ.

Лукша, М. (2013). “Белавежа” ў пацідзесяціпяці годдзе. Hiва, (27), 1.

Ніва. (b.d.). Pobrano 20 września 2013, z http://niva.bialystok.pl

Тычка, Г. (2000). Вачыма суседзяў. Беларуская літаратура ў Польшчы. Полымя, (12), 154-170.

Харытанюк-Міхей, Г. (2008). Пра беларускую літаратуру ў Польшчы: заўвагі бібліёграга. Sami o Sobie, (2), 12-13 [dodatek do „Przeglądu Prawosławnego” 2008 nr 12]

Хаўстовіч, М. (2010). Шляхамі да беларускасці: нарысыь, артыкуль, эсэ. Warszawa: Katedra Białorutenistyki Uniwersytetu Warszawskiego.

Чыквін, Я. (1998). Беларуская літаратура Польшчы: бібляграфічны даведнік 1957-1998. Беласток: Białoruskie Stowarzyszenie Literackie „Białowieża”.

\section{Bibliography (transliteration)}

50 lat slawistyki w Polskiej Akademii Nauk (1954-2004): ksiega jubileuszowa Instytutu Slawistyki PAN. (2004). Warszawa: Slawistyczny Ośrodek Wydawniczy.

Aleksijewicz, S. A. (2010). Wojna nie ma $w$ sobie nic z kobiety. (J. Czech, Trans.). Wołowiec: Wydawnictwo Czarne. 
Aleksijewicz, S. A. (2012). Czarnobylska modlitwa: kronika przyszłości. (J. Czech, Trans.). Wołowiec: Wydawnictwo Czarne.

Aleksijewicz, S. A. (2013). Ostatni świadkowie: utwory solowe na głos dziecięcy. (J. Czech, Trans.). Wołowiec: Wydawnictwo Czarne.

Aniempadystau, M., \& Wolski, L. (2000). Narodny albom: p’esa-scenariusz. (A. Wawrzeniuk, \& M. Wawrzeniuk, Tłum.). Białystok: Biblioteka Kartek.

Arłou, U. (2000). Requiem dla piły motorowej. (O. Łatyszonek, M. Łuksza, H. Maksymiuk, J. Maksymiuk, C. Seniuch, \& A. Wierzbicki, Trans., J. Maksymiuk, Ed.). Białystok: Związek Białoruski w RP.

Arłou, U. A. (2009). Prom przez kanał La Manche: wiersze. (A. Pomorski, Trans.). Gdańsk: Wydawnictwo Słowo/Obraz Terytoria.

Babina, N. (2010). Miasto ryb. (M. Buchalik, Trans.). Poznań: Dom Wydawniczy Rebis.

Barski, A. (1999). Nostalgie. (C. Seniuch, Trans.). Białystok: Orthdruk.

Barszczewski, L., \& Pomorski, A. (Eds.). (2008). Nie chyliłem czoła przed moca: antologia poezji białoruskiej od XV do XX wieku. Wrocław: Kolegium Europy Wschodniej im. Jana Nowaka-Jeziorańskiego.

Białoruś: kraina otoczona wysokimi górami. (2004). Olsztyn: Wspólnota Kulturowa „Borussia”. Bibliografia przekładów z literatury białoruskiej na język polski za okres 1971-1982. (1982).

Bibliografia Województw: Białostockiego, Łomżyńskiego i Suwalskiego. (1995) (Vol. 5: 1981-1985). Białystok: Wojewódzka Biblioteka Publiczna im. Łukasza Górnickiego w Białymstoku.

Bibliografia województwa podlaskiego: za lata 1986-2011. (n.d.). Retrieved September 20, 2013, from http://katalog.ksiaznicapodlaska.pl

Bibliografia Zawartości Czasopism. (n.d.). Retrieved September 20, 2013, from http://www. bn.org.pl

Bortnowska, K. (2009a). Białoruski postmodernizm: liryka pokolenia Bum-Bam-Litu. Warszawa: Wydawnictwa Uniwersytetu Warszawskiego.

Bortnowska, K. (2009b). Młoda literatura białoruska a polski rynek wydawniczy. Acta Albaruthenica, 9, 16-26.

Bykau, W. (1999). Ściana. (C. Seniuch, Trans.). Białystok: SETPro.

Chadanowicz, A., \& Pomorski, A. (Eds.). (2006). Pępek nieba: antologia młodej poezji białoruskiej. Wrocław: Kolegium Europy Wschodniej im. Jana Nowaka-Jeziorańskiego.

Charytoniuk, G. (1996). Literatura białoruska w Polsce. Bibliografia przekładów za lata 1945-1994. Białystok: Białoruskie Stowarzyszenie Literackie „Białowieża”.

Charytoniuk, G. (1998). Polskie białorutenika literackie. Bibliografia przedmiotowa 1945-1998. Białystok: Białoruskie Stowarzyszenie Literackie „Białowieża”.

Charytoniuk-Michiej, G. (2008). Pra belaruskuiu litaraturu ŭ Pol'shchy: zaŭvahi bibliiohraha. Sami o Sobie, (2), 12-13 [dodatek do „Przeglądu Prawosławnego” 2008 nr 12]

Chlebda, W., \& Kochman, S. (Eds.). (1996). Frazeologia i religia. Opole: Uniwersytet Opolski. Instytut Filologii Polskiej. 
Chowańska, I. (2011). W poszukiwaniu siebie: proza Michasia Stralcowa. Olsztyn: Centrum Badań Europy Wschodniej Uniwersytetu Warmińsko-Mazurskiego.

Chykvin, IA. (1998). Belaruskaia litaratura Pol'shchy: bibliagrafichny davednik 1957-1998. Belastok: Białoruskie Stowarzyszenie Literackie „Białowieża”.

Czasopis. (n.d.). Retrieved September 20, 2013, from http://czasopis.pl

Falkowska, J. (2005). Sokrat Janowicz (Sakrat Ânovič): materiały do bibliografii podmiotowoprzedmiotowej za lata 1956-2003 (Unpublished master's thesis). Wydział Historyczny Uniwersytetu Warszawskiego. Warszawa.

Fundacja Borussia Olsztyn. (n.d.). Retrieved September 20, 2013, from http://www.borussia.pl Fundacja Villa Sokrates. (n.d.). Retrieved September 20, 2013, from http://vimeo.com/ user20847765

Giej, M., \& Wielg, T. (Eds.). (2011). Na pograniczu nauk i kultur: tom poświęcony Profesorowi Bronisławowi Kodzisowi. Opole: Uniwersytet Opolski.

Instytut Filologii Wschodniosłowiańskiej. (n.d.). Retrieved September 20, 2013, from http:// ifw.uni.opole.pl

Instytut Neofilologii Wydziału Humanistycznego. (n.d.). Retrieved September 20, 2013, from http://www.in.uz.zgora.pl/index.php/badania-naukowe/nasze-ksiazki

Instytut Slawistyki Polskiej Akademii Nauk. (n.d.). Retrieved September 20, 2013, from http:// ispan.waw.pl

Janowicz, S. (2001). Ojczystość: białoruskie ślady i znaki. (R. Traba, Ed.). Olsztyn: Wspólnota Kulturowa „Borussia”.

Kamunikat. (n.d.). Retrieved September 20, 2013, from http://kamunikat.org

Karatkiewicz, U. S. (2012). Chrystus wylądowat w Grodnie: (ewangelia Judasza). (M. Buchalik, Trans.). Warszawa: Oficyna 21.

Katedra Białorutenistyki Uniwersytetu Warszawskiego. (n.d.). Retrieved September 20, 2013, from http://www.kb.uw.edu.pl

Kawalou, S. (2004). Zmęczony diabet: dramaty. (Giedz, M. Sajewicz, \& B. Siwek, Trans.). Lublin: Wydawnictwo Uniwersytetu Marii Curie-Skłodowskiej.

Kavalioŭ, S. V. (1993). Heroika-epichnaia paėziia Belarusi i Litvy kantsa XVI st. Minsk: Univèrsytètskae.

Kavalioŭ, S. V. (2002). Stanaŭlenne pol'skamoŭnaı̆ paėzii ŭ polilinhvistychnaĭ litaratury Belarusi épokhi Rènesansu. Minsk: BDU.

Khaŭstovich, M. V. (2010). Shliakhami da belaruskastsi: narysy, artykuly, èse. Warszawa: Katedra Białorutenistyki Uniwersytetu Warszawskiego.

Klinau, A. (2008). Mińsk: przewodnik po Mieście Słońca. (M. Buchalik, Trans.). Wołowiec: Wydawnictwo Czarne.

Kodzis, B., Kochman, S., \& Danecka, I. (Eds.). (1997). Literatury i języki Słowian Wschodnich: stan obecny i tendencje rozwojowe (Vol. 1-2). Opole: Uniwersytet Opolski.

Kojtych, E. (2010). Wiktor Szwed - biobibliografia (Unpublished master's thesis). Wydział Humanistyczny Uniwersytetu Warmińsko-Mazurskiego. Olsztyn. 
Kolegium Europy Wschodniej. (n.d.). Retrieved September 20, 2013, from http://www.kew.org.pl Kotkowicz, A., \& Kotkowicz-Klentak, V. (2003). Od Budsławia do GUŁagu. (A. Sobecka, Tłum.). Białystok: Białoruskie Towarzystwo Historyczne.

Koźbiał, J. (n.d.). O Katedrze. Retrieved September 20, 2013, from http://www.ksi.uw.edu.pl

Kwartalnik Literacko-Artystyczny Pobocza. (n.d.). Retrieved September 20, 2013, from http:// kwartalnik-pobocza.pl

Laszczak, W., \& Ambroziak, D. (Eds.). (2008). Ziemia w literaturach i myśli filozoficznej Słowian. Opole: Wydawnictwo Uniwersytetu Opolskiego.

Luksha, M. (2013). “Belavezha” ŭ patsidzesiatsipiatsi goddze. Niva, (27), 1.

Maksymiuk, J. (Red.). (1998). Za niebokresem Europy: antologia nowej poezji białoruskiej 1987-1998. Białystok: Rada Programowa Tygodnika „Niwa”.

Moskwin, A. (2013). Teatr białoruski 1920-1930: odrodzenie i zagłada. Toruń: Oficyna Wydawnicza Kucharski.

Niaklajeu, U. (2011). Pożegnalny gest Zygmunta: wiersze i poematy. (C. Seniuch, Trans.). Warszawa: Oficyna Literatów i Dziennikarzy POD WIATR.

Niva. (n.d.). Retrieved September 20, 2013, from http://niva.bialystok.pl

Ośrodek „Pogranicze - sztuk, kultur, narodów” w Sejnach. (n.d.). Retrieved September 20, 2013, from http://pogranicze.sejny.pl

Polska Bibliografia Literacka: za lata 1988-2000. (n.d.). Retrieved September 20, 2013, from http://pbl.ibl.poznan.pl/dostep

Polsko-białoruskie związki literackie i kulturalne: setna rocznica urodzin Janki Kupały i Jakuba Kołasa. (1982). Warszawa: Towarzystwo Przyjaźni Polsko-Radzieckiej.

Przewodnik Bibliograficzny. (n.d.). Retrieved September 20, 2013, from http://www.bn.org.pl

Razanau, A. (1997). Zdobywcy. (O. Łatyszonek, Trans.). Białystok: Kartki.

Roczniki Humanistyczne TN KUL. (n.d.). Retrieved September 20, 2013, from http://www. kul.pl/roczniki-humanistyczne-tn-kul-seria-slowianoznawstwo,art_4304.html

Sakowicz, A. (2012). Belaruskaia litaratura ŭ Pol'shchy: stylistychna-zhanravyia asablivastsi prozy belavezhan. Białystok.

Sawicka-Mierzyńska, K. (2012). Prowincja jako pole aktywności Stowarzyszenia Artystycznego „Kartki” In K. Kościewicz \& M. Kochanowski (Eds.), Podlasie w literaturze - literatura Podlasia (po 1989 roku): nowoczesność-regionalizm-uniwersalizm (pp. 296-321). Białystok: Trans Humana Wydawnictwo Uniwersyteckie.

Siwek, B. (2004). Ojczyzna duża i mała: poeci Białoruskiego Stowarzyszenia Literackiego „Białowieża" wobec problematyki ojczyźnianej. Lublin: Wydawnictwo KUL.

Siwek, B. (2011). Wolność ukrzyżowana: rzecz o białoruskim dramacie i teatrze. Lublin: Wydawnictwo KUL.

Siwek, B. (Ed.). (2013). Labirynt: antologia współczesnego dramatu białoruskiego. Radzyń Podlaski: Radzyńskie Stowarzyszenie Inicjatyw Lokalnych.

Supa, W. (Ed.). (1993-2008). Satyra w literaturach wschodniosłowiańskich (Vol. 1-7). Białystok: Wydawnictwo Uniwersytetu w Białymstoku. 
Szerszunowicz, W. (1985). Kazimierz Andrzej Jaworski jako tłumacz i popularyzator poezji białoruskiej. Studia Polono-Slavica-Orientalia. Acta Litteraria, 9, 124-130.

Szwed, W. (2000a). Lata wiatr skrzydlaty. (W. Szwed, Trans.). Białystok: Orthdruk.

Szwed, W. (2000b). Śmiech nie grzech. Białystok: Orthdruk.

Tychka, G. (2000). Vachyma susedziaŭ. Belaruskaia litaratura ŭ Pol'shchy. Polymia, (12), 154-170.

Vaŭraniuk, M. (2000). Chartapolokh na miazhy. Pravintsyia, 1-2, 4-9.

Voranau, V. (2013). Wielkie Księstwo Białoruś. (M. Uranek, Trans.). Gniezno: Zeszyty Poetyckie.

Wielg, T. (2002). Poetyka prozy Wasila Bykawa. Opole: Wydawnictwo Uniwersytetu Opolskiego. Wielkie tematy kultury $w$ literaturach słowiańskich. (1997-2012) (Vol. 1-10). Wrocław: Wydawnictwo Uniwersytetu Wrocławskiego.

Woźniak, A., \& Kowalczyk, W. (Eds.). (2010). W kręgu wartości: Bóg, człowiek, świat w kulturze i literaturach wschodniosłowiańskich. Lublin: Wydawnictwo Uniwersytetu Marii Curie-Skłodowskiej.

Zaniewska, T. (1992). Podróż daremna: szkice o literaturze białoruskojęzycznej w Polsce. Białystok: Biblioteczka Białoruskiego Stowarzyszenia Literackiego „Białowieża”.

Zaniewska, T. (1997). Strażnicy pamięci: poezja białoruskojęzyczna w Polsce po roku 1956. Białystok: Trans Humana.

\section{Belarusian literature in Poland after 1989. About the necessity of developing a literature database}

\section{Summary}

Speaking about Belarusian literature in Poland we focus on fiction, its translation into Polish and the study of literature. The existence of the Belarusian literature in Poland in the post-war period is indicated by the following bibliographies: a bibliography of translations for the period 1945-1994 (G. Charytoniuk, Literatura białoruska w Polsce. Bibliografia przekładów za lata 1945-1994, Białystok 1996) and a subject bibliography for the period 1945-1998 (G. Charytoniuk, Polskie białorutenika literackie. Bibliografia przedmiotowa 1945-1998, Białystok 1998). The new political, economical and social conditions in Poland after 1989 have had an influence on the situation of the Belarusian literature. In addition to the existing departments some new university departments and scientific branches have been organized. Their aim is to realize new scientific 
projects connected with the Belarusian literature in Poland and Belarus. A lot of nongovernment organizations (funds, partnerships, associations) have been organized not only in Bialystok region, but also in the other parts of the country. A new publishing market has been established which has focused on the modern literature of Central and Eastern Europe including Belarusian literature. The Internet also plays an important role in popularization of the Belarusian literature. That literature has been included in the database of the National library (Przewodnik Bibliograficzny, Bibliografia Zawartości Czasopism), regional libraries (Bibliografia województwa podlaskiego) and the digital library (Polska Bibliografia Literacka). The information is searched by institutional scientific depositories and digital libraries. The considerable part of the information has not been registered in the bibliographic database. In this situation it is necessary to develop an integral literature bibliographic database of the Belarusian literature in Poland.

Keywords: bibliography; literature database; Belarusian literature in Poland; scientific descriptions; translation

Słowa kluczowe: baza danych; literacka baza danych; bibliografia; literatura białoruska w Polsce; opracowania naukowe; przekład 